\title{
IN HONOR OF STEPHEN GUISINGER
}

Professor Stephen Guisinger, a member of the JIBS Editorial Board and a good friend, died in Dallas, Texas on July 3, 2001. He suffered heart failure following emergency surgery for a previously undetected cancer.

Steve had enjoyed a distinguished career as a scholar and teacher of international business, and he had been active in governmental policymaking circles as a specialist in foreign direct investment issues and business-government relations. His publications included articles in JIBS in 1989, 1991, 1992 and 1995 as well as 1998. He inspired and co-edited the symposium in the journal on "Multinational Enterprise and Economic Analysis" (Volume 29, Number 1). He had recently begun working on an IB textbook based on his analytic framework emphasizing the interactions of firms with their political-economic environments. He worked with numerous doctoral students in his career, and was always a strong supporter of them during and after their studies.

Perhaps less known to members of the AIB were his professional activities on government policy issues-for instance, as a frequent consultant to the World Bank on foreign direct investment issues, particularly in Asia. He was also directly involved in drafting the Asia Pacific Economic Cooperation (APEC) code on foreign direct investment.

Steve had been robust-and energetically looking forward to the future- until a few days before his death. I'm sure many of us will continue to be inspired by his example.

By Thomas L. Brewer 